\title{
Effects of intact and hydrolysed blue whiting proteins on blood pressure and markers of kidney function in obese Zucker fa/fa rats
}

\author{
Aslaug Drotningsvik ${ }^{1,2}$ - Åge Oterhals ${ }^{3}\left[\right.$ - Svein Are Mjøs $s^{4}\left(\right.$ Linn Anja Vikøren $^{5} \cdot$ Ola Flesland $^{2}$. \\ Oddrun Anita Gudbrandsen ${ }^{1}$ (1)
}

Received: 25 January 2020 / Accepted: 24 April 2020 / Published online: 14 May 2020

(c) The Author(s) 2020

\begin{abstract}
Purpose To investigate the effects of diets containing intact or hydrolysed proteins from blue whiting (Micromesistius poutassou) on the development of high blood pressure and markers of kidney function in obese Zucker fa/fa rats which are prone to develop hypertension and renal failure.

Methods Male rats were fed isocaloric diets containing either intact blue whiting whole meal (BW-WM), blue whiting protein hydrolysate prepared with Alcalase ${ }^{\circledR}$ (BW-HA) or blue whiting protein hydrolysate prepared with Protamex ${ }^{\circledR}$ (BW-HP) as $1 / 3$ of total protein with the remaining $2 / 3$ as casein, or casein as sole protein source (control group). Blood pressure was measured at Day 0 and Day 32. Rats were housed in metabolic cages for $24 \mathrm{~h}$ for collection of urine in week 4 . After 5 weeks, rats were euthanized and blood was drawn from the heart. The renin and angiotensin-converting enzyme (ACE) inhibition capacities for casein and blue whiting proteins were measured in vitro.

Results The blood pressure increase was lower in rats fed diets containing blue whiting proteins when compared to the control group, whereas markers of kidney function were similar between all groups. The three blue whiting proteins inhibited renin activity in vitro, whereas casein had no effect. The in vitro ACE inhibition was similar for casein, BW-WM and BW-HP proteins, whereas BW-HA protein was less potent.

Conclusion Blue whiting protein feeding attenuated the blood pressure increase in obese Zucker fa/fa rats, possibly mediated through the renin-angiotensin system and without affecting markers of kidney function.
\end{abstract}

Keywords Fish proteins $\cdot$ Blood pressure $\cdot$ Hypertension $\cdot$ Obesity $\cdot$ Zucker $\cdot$ Rat

\section{Introduction}

Electronic supplementary material The online version of this article (https://doi.org/10.1007/s00394-020-02262-9) contains supplementary material, which is available to authorized users.

Oddrun Anita Gudbrandsen

oddrun.gudbrandsen@k1.uib

1 Dietary Protein Research Group, Department of Clinical Medicine, University of Bergen, Haukeland University Hospital, 5021 Bergen, Norway

2 TripleNine Vedde AS, 6030 Langevåg, Norway

3 Nofima, 5828 Bergen, Norway

4 Department of Chemistry, University of Bergen, 5020 Bergen, Norway

5 Department of Clinical Science, University of Bergen, 5021 Bergen, Norway
High blood pressure is associated with increased risk of chronic renal and cardiovascular diseases [1-3]. Lifestyle modifications are recommended to prevent hypertension [4], and several studies show that a high fish intake is associated with lower blood pressure [5-12]. A blood pressure-lowering effect of fish may be mediated through the angiotensin-renin system, since peptides with angiotensin-converting enzyme (ACE) inhibiting capacities in vitro have been identified in fish fillet, skin and backbone [13], but evidence concerning in vivo effects of fish proteins on blood pressure is limited. Angiotensinogen is cleaved by renin to the biologically inactive angiotensin I, which is then converted to the active vasoconstrictor angiotensin II by ACE, with the cleavage of angiotensinogen by renin as the rate determining step [14]. 
The obese Zucker fa/fa rat is a much used model of genetic obesity and has been shown to be well suited for studies on metabolic complications and treatments of obesity and hypertension [15]. These rats develop visible obesity from the age of 3-4 weeks and develop an agerelated increase in blood pressure already before the age of 10 weeks [15-17], and with increasing age they also spontaneously develop proteinuria and focal segmental glomerulosclerosis leading to renal failure [18].

Fish meals (non-hydrolysed) produced from Atlantic cod (Gadus morhua) residual materials or fillet have shown potential to prevent blood pressure increase and beneficially affect markers of kidney function in obese Zucker fa/fa rats [19, 20]. Blue whiting (Micromesistius poutassou) is a small pelagic fish primarily used to produce fish meal for aquaculture feed and belongs to the family Gadidae included in the order Gadiformes (codfishes) together with, among others, the Atlantic cod. The market for blue whiting as whole fish or fillet for human intake is limited by factors such as small size and discoloration [21], and blue whiting products based on fish meal or protein hydrolysates may be one option to improve the utilization of this fish species. We have recently shown that a water-soluble protein meal from blue whiting has a hypocholesterolemic effect in obese Zucker fa/fa rats [22], but more knowledge on the potential health effects of proteins from blue whiting is warranted to expand its usability in new products for human consumption. Enzymatic hydrolysis enables efficient recovery of proteins from fish and fish by-products and produces protein fractions with higher content of small peptides that may exert effects as bioactive compounds. Blue whiting protein hydrolysates have been shown to have ACE-inhibiting properties in vitro [23, 24], but the effects of blue whiting hydrolysates on blood pressure and markers of kidney function in vivo have not yet been investigated.

The primary objective of the present study was to compare the effects of diets containing proteins from headed and gutted blue whiting as whole meal or protein hydrolysates on the development of high blood pressure in obese Zucker fa/fa rats. The secondary objectives were to investigate any changes in markers of kidney function, organ damage, inflammation and oxidative stress, to examine the in vitro renin and ACE-inhibiting properties of the blue whiting proteins, and to explore the possible impact of dietary components in the blue whiting protein meals that could affect blood pressure development. Our hypothesis was that blue whiting protein intake would attenuate the development of high blood pressure in obese Zucker fa/fa rats possibly through inhibition of the renin-angiotensin system, and beneficially affect markers of kidney function.

\section{Methods}

\section{Ethical statement}

The study protocol was approved by the National Animal Research Authority (Norway) in accordance with the Animal Welfare Act and the Regulation of animal experiments (Approval No. 2014/6979). All applicable international, national and institutional guidelines for the care and use of animals were followed.

\section{Animals and diets}

Twenty-four male obese Zucker fa/fa rats (HsdHlr:ZUCKER-Leprfa) were obtained from Harlan Laboratories (Indianapolis, IN, USA). The rats were housed in pairs in Macrolon IV cages (EHRET GmbH \& Co.) in a room with a $12 \mathrm{~h} \mathrm{light/dark} \mathrm{cycle,} \mathrm{at} 20-23{ }^{\circ} \mathrm{C}$ and a relative humidity of $55-65 \%$. Rats were acclimatized for a minimum of 7 days under these conditions, before being randomly allocated to intervention groups or control group, with six rats in each group. The intervention period started when the rats were 8-9 weeks old and weighed $319 \pm 11 \mathrm{~g}$. The number of rats per group was chosen based on previous experience from studies on the development of high blood pressure in obese Zucker fa/ fa rats [25]. Rats were fed modified semi-purified diets based on the American Institute of Nutrition's recommendation for growing laboratory rodents (AIN-93G) [26] with the addition of $1.6 \mathrm{~g}$ methionine $/ \mathrm{kg}$ diet as recommended by Reeves [27], and differed only in their protein sources (Table 1). All diets contained 20wt\% protein. The AIN-93G diet was used instead of the AIN-93 M diet for maintenance containing $15 \mathrm{wt} \%$ protein, since rats would be in the growth phase throughout the intervention period (based on growth charts for Zucker rats from Harlan Laboratories, https://www.envigo.com). In addition, obese Zucker rats have an impaired protein metabolism, which leads to inferior protein utilization and requires a greater protein intake to maintain a maximal rate of protein gain during growth [28]. The three intervention diets contained fish proteins produced from the same batch of headed and gutted blue whiting. All blue whiting protein diets contained $1 / 3$ (by weight) of total dietary protein from blue whiting and the remaining $2 / 3$ (by weight) of protein was casein. Blue whiting proteins were in the form of either blue whiting whole meal (BW-WM), blue whiting protein meal hydrolysate prepared with Alcalase ${ }^{\circledR}$ (BWHA), or blue whiting protein meal hydrolysate prepared with Protamex ${ }^{\circledR}$ (BW-HP). Casein was the sole protein source in the control diet (Table 1). All ingredients were 
Table 1 Composition of the experimental diets

\begin{tabular}{|c|c|c|c|c|}
\hline Contents ( $\mathrm{g} / \mathrm{kg}$ diet $)$ & Control diet & BW-WM diet & BW-HA diet & BW-HP diet \\
\hline Casein $^{a}$ & 216.0 & 144.0 & 144.0 & 144.0 \\
\hline Blue whiting whole meal protein ${ }^{\mathrm{b}}$ & - & 93.3 & - & - \\
\hline Blue whiting protein hydrolysed with Alcalase ${ }^{\circledR c}$ & - & - & 87.7 & - \\
\hline Blue whiting protein hydrolysed with Protamex ${ }^{\circledR d}$ & - & - & - & 85.3 \\
\hline Cornstarch & 511.7 & 490.5 & 496.3 & 498.5 \\
\hline Sucrose & 90.0 & 90.0 & 90.0 & 90.0 \\
\hline Cellulose & 50.0 & 50.0 & 50.0 & 50.0 \\
\hline Soybean oil & 70.0 & 70.0 & 70.0 & 70.0 \\
\hline t-Butylhydroquinone (TBHQ) & 0.015 & 0.015 & 0.015 & 0.015 \\
\hline Mineral mix (AIN-93-MX) & 35.0 & 35.0 & 35.0 & 35.0 \\
\hline Vitamin mix (AIN-93-VX) & 10.0 & 10.0 & 10.0 & 10.0 \\
\hline L-Methionine & 1.6 & 1.6 & 1.6 & 1.6 \\
\hline L-Cystine & 3.0 & 3.0 & 3.0 & 3.0 \\
\hline Choline bitartrate $\mathrm{e}^{\mathrm{e}}$ & 2.5 & 2.5 & 2.5 & 2.5 \\
\hline Growth and maintenance supplement ${ }^{\mathrm{f}}$ & 10.0 & 10.0 & 10.0 & 10.0 \\
\hline
\end{tabular}

$B W$ - $W M$ blue whiting whole meal $B W-H A$ blue whiting protein hydrolysate prepared with Alcalase ${ }^{\circledR}, B W$ $H P$ blue whiting protein hydrolysate prepared with Protamex ${ }^{\circledR}$

${ }^{a}$ Contains $92.5 \%$ crude protein, $<1 \%$ fat, $8 \%$ moisture, $<1 \%$ ash

${ }^{\mathrm{b}}$ Contains $71.4 \%$ crude protein, $5 \%$ fat, $8 \%$ moisture, $9 \%$ ash

${ }^{\mathrm{c}}$ Contains $76.0 \%$ crude protein, $<0.01 \%$ fat, $5 \%$ moisture, $13 \%$ ash

${ }^{\mathrm{d}}$ Contains $78.2 \%$ crude protein, $<0.01 \%$ fat, $3 \%$ moisture, $12 \%$ ash

${ }^{\mathrm{e}}$ Contains $41 \%$ choline

${ }^{\mathrm{f}}$ Contains vitamin B12 (40 mg/kg) and vitamin K1 $(25 \mathrm{mg} / \mathrm{kg})$ mixed with sucrose $(995 \mathrm{~g} / \mathrm{kg})$ and dextrose $(5 \mathrm{~g} / \mathrm{kg})$ purchased from Dyets Inc. (Bethlehem, PA, USA) except casein which was purchased from Sigma-Aldrich (Munich, Germany) and fish proteins which were prepared from blue whiting by Nofima (Bergen, Norway).

\section{Preparation of blue whiting proteins}

The blue whiting was frozen on-board the fishing vessel, landed and then partially thawed at ambient temperature, and headed and gutted before further freeze storage until use. To produce whole meal, the frozen headed and gutted fish was partially thawed overnight, added equal amount of water and heated to $90{ }^{\circ} \mathrm{C}$ in a $150 \mathrm{~L}$ steam-heated kitchen cooker. After 10 min holding time, the cooked material was mechanically dewatered in a P13-SCR double-screw press (Stord Bartz AS, Bergen, Norway). The press liquid was heated to $90{ }^{\circ} \mathrm{C}$ and run through a Jesma VS 20/65 Roto-Fluid sieve (Jesma, Velje, Denmark; $100 \mu \mathrm{m}$ sieve net opening) to remove suspended solids. The Jesma solids was mixed with the press cake and dried to a press cake fish meal on a TG1 fluid bed dryer (Retsch GmbH \& Co. KG, Germany) at $70{ }^{\circ} \mathrm{C}$. The Jesma liquid was evaporated on a four-stage falling film evaporator (APV Anhydro, Søborg, Denmark) at $60-100{ }^{\circ} \mathrm{C}$. The concentrate was mixed with an equivalent amount of press cake fish meal and dried on a TG1 fluid bed dryer at $70{ }^{\circ} \mathrm{C}$ to obtain a whole meal. The whole meal was milled on a Retsch ZM-1 centrifugal mill (Retsch GmbH, Haan, Germany) with a ring sieve aperture of $0.75 \mathrm{~mm}$.

Two different protein hydrolysates were produced from the headed and gutted blue whiting. The headed and gutted fish was partially thawed and processed on a meat grinder with $7.5 \mathrm{~mm}$ aperture and was added an equal amount of water in a $200 \mathrm{~L}$ stirred tank reactor. The fish slurry was heated to $50{ }^{\circ} \mathrm{C}$ under continuous stirring before addition of the following combinations of enzyme (given on crude protein basis) and residence time: Alcalase ${ }^{\circledR} 2.4 \mathrm{~L}$ (Novozymes AS, Bagsværd, Denmark) 0.5\%, residence time $60 \mathrm{~min}$ and Protamex ${ }^{\circledR}$ (Novozymes AS, Bagsværd, Denmark) $1 \%$, residence time $60 \mathrm{~min}$. After the predefined residence time, the hydrolysates were heated to $90{ }^{\circ} \mathrm{C}$ and kept at this temperature level for $10 \mathrm{~min}$ to inactivate the enzyme. The hydrolysates were filtrated on a Jesma VS 20/65 Roto-Fluid sieve (Jesma, Velje, Denmark; $100 \mu \mathrm{m}$ sieve net opening) before microfiltration by use of Membralox (Pall Corporation, Portsmouth, UK) ceramic membranes with pore size $100 \mathrm{~nm}$, removing all fats in the hydrolysates. The permeates were concentrated in a four-stage falling film evaporator (APV Anhydro, Soeborg, Denmark) at $60-100{ }^{\circ} \mathrm{C}$ before final drying. The Alcalase ${ }^{\circledR}$ protein hydrolysate was dried 
in a Christ Gamma 1-16 LSC freeze dryer (Martin Christ Gefriertrocknungsanlagen GmbH, Osterode am Harz, Germany), and the Protamex ${ }^{\circledR}$ protein hydrolysate in a Niro P-6.3 spray drier (Niro, Sjøborg, Denmark) with inlet and outlet temperature 200 and $94{ }^{\circ} \mathrm{C}$, respectively. The dried Alcalase ${ }^{\circledR}$ protein hydrolysate was milled on a Retsch ZM-1 centrifugal mill with a ring sieve aperture of $1.0 \mathrm{~mm}$, while the Protamex ${ }^{\circledR}$ protein hydrolysate was used as is.

\section{Design}

Rats were fed ad libitum for 5 weeks, with free access to tap water and chewing sticks. Rats were weighed weekly during the intervention period. One week before end point, rats were housed individually in metabolic cages (Ancare Corp., NY, USA) for $24 \mathrm{~h}$ for collection of urine and measurement of feed intake, without fasting in advance. Blood pressure was measured in conscious rats at baseline (Day 0 ) and 3 days before end point (Day 32). At the end of the experimental period, after a $12 \mathrm{~h}$ fast, rats were euthanized while anaesthetized with isoflurane (Isoba vet, Intervet, Schering-Plough Animal Health, Boxmeer, The Netherlands) mixed with nitrous oxide and oxygen. Blood was drawn from the heart and collected in Vacuette Z Serum Clot Activator Tubes for isolation of serum (Greiner Bio-One, Austria) and in Vacuette K2EDTA tubes (Greiner Bio-One) for isolation of plasma. Liver and epididymal white adipose tissue (WATepi) were dissected out and frozen. All biological samples were stored at $-80^{\circ} \mathrm{C}$.

\section{Analyses of diets}

Contents of amino acids (except $\alpha$-aminobutyric acid, $\beta$-alanine, $\gamma$-aminobutyric acid, citrulline, 4-hydroxyproline, 1-methylhystidine and 3-methylhistidine), energy and sodium content in diets, and crude protein, fat, moisture, ash and peptide size distribution of blue whiting protein meals, were measured by Nofima BioLab (Bergen, Norway). Amino acids were measured using HPLC [29]. Dietary caloric content was determined by a bomb calorimeter method in accordance with ISO9831:1998 [30] using a Parr 6400 calorimeter (Parr Instrument Company, Illinois). Dietary sodium content was determined by flame atomic absorption spectrometry in accordance with ISO6869:2000 [31] using Perkin Elmer Analyst 400 with an AS 90plus autosampler (PerkinElmer, Massachusetts). Crude protein was determined according to the Kjeldahl method [32]. Fat content was determined gravimetrically after chloroform/methanol extraction [33]. Moisture content was measured gravimetrically after drying in a forced-air oven at $103 \pm 1{ }^{\circ} \mathrm{C}$ for $4.5 \mathrm{~h}$ [34]. Total ash content was determined gravimetrically after incineration at $550{ }^{\circ} \mathrm{C}$ [35]. Peptide size distributions for the blue whiting proteins were measured by HPLC size exclusion chromatography as described previously [36]. Fatty acid composition of diets was analysed by gas chromatography after lipid extraction as described below.

$\alpha$-Aminobutyric acid, $\beta$-alanine, $\gamma$-aminobutyric acid, citrulline, 4-hydroxyproline, 1-methylhystidine ( $\pi$-methylhistidine), 3 -methylhistidine ( $\tau$-methylhistidine) and taurine were quantified in diets as described below, after total acid hydrolysis $\left(6 \mathrm{M} \mathrm{HCl}, 24 \mathrm{~h}, 110{ }^{\circ} \mathrm{C}\right)$.

\section{Renin and ACE inhibition in vitro}

Casein and BW-WM protein were added Trizma buffer (50 mM, pH 8.0) and hydrolysed using trypsin from bovine pancreas (T1426 from Sigma) at $45{ }^{\circ} \mathrm{C}$ for $4 \mathrm{~h}$ as recommended by Shalaby et al. [37]. The two blue whiting protein hydrolysates (BW-HA, BW-HP) were not hydrolysed with trypsin prior to analyses. Protein in hydrolysates were quantified on the Cobas c111 system (Roche Diagnostics $\mathrm{GmbH}$, Mannheim, Germany) using the TP2 kit from Roche. Renin inhibition was measured using the Renin Assay Kit (MAK157, from Sigma-Aldrich) as described in the user manual. ACE-inhibition was measured using the method by Shalaby et al. [37], as previously described [20].

\section{Blood pressure measurements}

Systolic and diastolic blood pressures were measured at baseline and end point. Rats were pre-warmed in a heating cabinet at $32{ }^{\circ} \mathrm{C}$ for $30 \mathrm{~min}$ before blood pressure was measured using the tail-cuff method (CODA-6, Kent Scientific Corporation, Torrington, CT, USA).

\section{Analyses in serum, plasma, urine and kidney}

Serum concentrations of creatinine, alanine transaminase and aspartate transaminase (the latter two were measured with pyridoxal phosphate activation), and urine concentrations of creatinine, total protein, carbamide, uric acid and ammonium were analysed on the Cobas c111 system (Roche Diagnostics GmbH, Mannheim, Germany) using the CREP2 (Creatinine plus ver.2), ALTL (Alanine aminotransferase acc. IFCC), ASTL (Aspartate aminotransferase), TP2 (Total Protein Gen. 2 monochromatic), UREAL (Urea/BUN), UA2 (Uric Acid ver.2) and NH3L (Ammonia) kits from Roche Diagnostics. Sodium concentrations in serum and urine were analysed on the Cobas c111 system (Roche Diagnostics GmbH, Mannheim, Germany) using the Ion-Selective Electrode module from Roche Diagnostics.

Plasma and urine concentrations of cystatin $\mathrm{C}$ were quantified using the Mouse/Rat Cystatin C Quantikine ${ }^{\circledR}$ ELISA (catalogue number MSCTC0) from R\&D Systems, BioTechne, MN. 
Plasma for glutathione measurements was added to four volumes of ice-cold 5\% meta-phosphoric acid, mixed and stored on ice for $15 \mathrm{~min}$ before centrifugation, and the supernatant was stored at $-80^{\circ} \mathrm{C}$ until analysis. Total and oxidized glutathione were analysed using the Glutathione (GSSG/GSH) detection kit (ADI-900-160) from Enzo Life Sciences AG, Lausen, Switzerland. Reduced glutathione was calculated as the difference between total and oxidized glutathione.

Serum concentrations of monocyte chemoattractant protein (MCP)-1, interleukin (IL)-1b, IL-6 and tumor necrosis factor (TNF) $\alpha$ were measured using the MILLIPLEX ${ }^{\circledR}$ MAP Rat Cytokine/Chemokine Magnetic Bead Panel (RECYTMAG-65 K) from EMD Millipore Corp. (St. Charles, MO).

Kidneys were homogenized in Tris-buffer ( $\mathrm{pH} 7.8)$ before analyses of T cell immunoglobulin mucin-1 (TIM-1), using the Rat TIM-1/KIM-1/HAVCR Quantikine ${ }^{\circledR}$ ELISA (catalogue number RKM100) from R\&D Systems. Kidney protein content was measured with the Bradford dye-binding method [38] using Protein Assay Dye Reagent (Bio-Rad Laboratories, Germany) with bovine serum albumin (BioRad Protein Assay Standard II, Bio-Rad Laboratories) as standard.

\section{Amino acids in plasma, urine and $\mathrm{HCl}$-hydrolysed diets}

Free amino acids in EDTA-plasma and urine, and total amino acids in $\mathrm{HCl}$-hydrolysed diets were quantified by reverse-phase high performance liquid chromatography, using the S 433 Automatic Amino Acid Analyser (Sykam $\mathrm{GmbH}$, Eresing, Germany), equipped with integrated dual-channel photometer for the detection of amino acids at $440-570 \mathrm{~nm}$, cooled autosampler and reagent storage, and integrated vacuum degasser. The autosampler and reagent storage were kept at $13-14{ }^{\circ} \mathrm{C}$, and total acquisition time was $111 \mathrm{~min}$. Mobile phases were lithium citrate buffer A-1 $(0.12 \mathrm{~N}, \mathrm{pH} 2.90)$, lithium citrate buffer B-1 $(0.30 \mathrm{~N}, \mathrm{pH} 4.20)$, lithium citrate/borate buffer C-4 $(0.30 \mathrm{~N}, \mathrm{pH} 8.0)$ and regeneration solution $(0.45 \mathrm{~N})$ (all for physiological program, from Sykam $\mathrm{GmbH}$ ), with postcolumn derivatization with ninhydrin (Sykam $\mathrm{GmbH}$ ). The mobile phases were delivered according to the following scheme at constant flow of $0.450 \mathrm{ml} / \mathrm{min}: 0-12.50 \mathrm{~min}$, 100\% buffer A-1; $12.60-38.00$ min: $74 \%$ buffer A-1/26\% buffer B.1; 38.10-50.00 min: $46 \%$ buffer A-1/54\% buffer B-1; 50.10-62.00 min: 22\% buffer A-1/78\% buffer B-1; 62.10-63.50 min: 100\% buffer B-1; 63.60-71.00 min: 76\% buffer B-1/24\% buffer C-4; 71.10-85.00 min: $100 \%$ buffer C-4; 85.10-94.00 min: 80\% buffer C-1/20\% Regeneration solution, $94.10-107.00 \mathrm{~min}$ : 74\% buffer C-4/26\% regeneration buffer, $107.10-111.00 \mathrm{~min}: 100 \%$ regeneration buffer. Column oven temperature was $39^{\circ} \mathrm{C}(0-88 \mathrm{~min}), 60{ }^{\circ} \mathrm{C}$
(88-89 min); $70{ }^{\circ} \mathrm{C}$ (89-111 min). Amino acids were derivatized post-column with ninhydrin (Sykam $\mathrm{GmbH})$, with a constant reactor temperature of $130{ }^{\circ} \mathrm{C}$. Clarity Amino chromatography station version 7.4.1.99 (Sykam $\mathrm{GmbH}$ ) was used for data acquisition and analysis. Plasma and urine samples for quantification of amino acids were prepared as follows: four volumes of plasma or urine was added to one volume of 5-sulfosalicylic acid dihydrate (Sigma-Aldrich, Munich, Germany), containing the internal standard norleucine (Sigma-Aldrich), to precipitate proteins. After centrifugation $(2000 \times g, 5 \mathrm{~min})$, the supernatant from plasma was diluted 1:1 with Lithium citrate buffer A-1 (Sykam GmbH), whereas the supernatant from urine was diluted $2: 1$ with the same buffer. The amino acid standard stock solution for physiological samples (PH, from Sykam $\mathrm{GmbH}$ ) added to L-glutamine (Sigma-Aldrich) was used as calibrator. $\gamma$-Aminobutyric acid and $\beta$-alanine were quantified in urine but were not found in plasma, and tryptophan was quantified in plasma but could not be quantified in urine. Otherwise the same compounds were analysed in plasma and urine. Only $\alpha$-aminobutyric acid, $\beta$-alanine, $\gamma$-aminobutyric acid, citrulline, 4-hydroxyproline, 1-methylhystidine ( $\pi$-methylhistidine), 3 -methylhistidine ( $\tau$-methylhistidine) and taurine were quantified using this method in the diets.

\section{Fatty acids in serum, liver, WATepi and diets}

Lipids in liver and diets were extracted according to the method described by Bligh and Dyer [33] using a mixture of methanol and chloroform, before methylation. Serum and WATepi were methylated without prior extraction of lipids. Fatty acids in liver and diet extracts, serum and WATepi were analysed by gas chromatography as described previously [39].

\section{Statistical analyses}

Statistical analyses were conducted using SPSS Statistics version 25 (SPSS, Inc., IBM Company, Armonk, NY, USA). All variables were evaluated for normality using the Shapiro-Wilks test, Q-Q plots and histograms and most variables were normally distributed. One-way analysis of variance (ANOVA) was used to compare groups, followed by the Fisher's LSD post hoc test to determine significant differences between groups when appropriate. All biological data are presented as means \pm standard deviations. Bivariate correlations were calculated using Pearson's two-tailed test of significance. Results from the measurements of renin and ACE inhibition by dietary proteins are presented as means \pm standard error of mean. The cut off value for statistical significance was set at a probability of 0.05 . One rat in the control group was excluded from all statistical analyses due to apparent disease, thus results are presented 
as $N=5$ rats for the control group and $N=6$ rats for each of the intervention groups.

\section{Results}

\section{Blue whiting protein peptide size distribution}

Analyses of peptide size distribution showed that the enzymatic hydrolysis protocols were sufficient to produce $>80 \%$ of peptides with a molecular size below $4000 \mathrm{~g} /$ mol (83.5 and $91.2 \%$ in hydrolysates BW-HA and BW-HP, respectively) and the hydrolysates contained negligible quantities of large proteins $>20,000 \mathrm{~g} / \mathrm{mol}$ (Table 2). The watersoluble protein fraction of the non-hydrolysed BW-WM consisted of $29.5 \%$ peptides with molecular weight $>20,000 \mathrm{~g} /$ mol and the peptide fraction with molecular weight $<200 \mathrm{~g} /$ mol (comprising free amino acids and miscellaneous watersoluble components absorbing light with a wavelength of $214 \mathrm{~nm}$ ) amounted to $45.3 \%$.

\section{Diets, dietary intake, growth and organ weights}

Dietary contents of indispensable amino acids were in general similar between the diets (Table 3); however the content of the conditionally essential amino acid arginine was higher in all blue whiting protein diets. $\beta$-Alanine, 3 -methylhistidine and taurine were detected only in blue whiting protein diets, with highest amount in BW-HA and BW-HP. 4-Hydroxyproline and 1-methylhystidine were also found only in diets containing blue whiting meal, with little differences between

Table 2 Molecular weight distribution of water-soluble peptides

\begin{tabular}{lccc}
\hline g/mol & $\begin{array}{l}\text { BW-WM } \\
\text { protein }\end{array}$ & BW-HA protein & BW-HP protein \\
\hline$>20,000$ & 29.5 & 0.4 & $<$ LOD \\
$20,000-15,000$ & 4.5 & 0.3 & $<$ LOD \\
$15,000-10,000$ & 5.1 & 1.2 & 0.4 \\
$10,000-8000$ & 2.4 & 1.8 & 0.9 \\
$8000-6000$ & 2.1 & 4.0 & 2.2 \\
$6000-4000$ & 1.8 & 8.6 & 5.4 \\
$4000-2000$ & 1.5 & 18.4 & 15.1 \\
$2000-1000$ & 0.8 & 20.2 & 20.1 \\
$1000-500$ & 0.7 & 14.9 & 19.3 \\
$500-200$ & 6.4 & 12.2 & 17.5 \\
$<200^{\mathrm{a}}$ & 45.3 & 17.8 & 19.2 \\
\hline
\end{tabular}

$B W$-WM blue whiting whole meal, $B W-H A$ blue whiting protein hydrolysate prepared with Alcalase ${ }^{\circledR}, B W-H P$ blue whiting protein hydrolysate prepared with Protamex ${ }^{\circledR}, L O D$ level of detection

${ }^{\text {a }}$ The peptide fraction with molecular weight $<200 \mathrm{~g} / \mathrm{mol}$ comprises free amino acids and miscellaneous water-soluble components absorbing light with a wavelength of $214 \mathrm{~nm}$ ) these diets. The content of $\gamma$-aminobutyric acid was lower in the blue whiting containing diets compared to the control diet. The amounts of $\alpha$-aminobutyric acid and citrulline were below the level of detection in all diets. Arachidonic acid (20:4n-6) and the n-3 PUFAs 20:5n-3, 22:5n-3 and 22:6n-3 ( $\Sigma \mathrm{n}-3$ PUFA $0.11 \mathrm{wt} \%$ ) were detected only in the BW-WM diet, otherwise fatty acid composition was similar between diets.

Body weight at baseline, body weight-to-body length ratio at euthanasia, weight of WATepi relative to body weight and daily energy and protein intake measured at week 4 were similar between groups (Table 4). The percent growth from baseline to end point was higher in the BW-HA and BW-HP groups compared to control group, and was higher in BW-HA group compared to BW-WM group. Otherwise, growth was similar between groups.

The sodium content was higher in all blue whiting protein diets compared to the control diet, resulting in a higher sodium intake in all blue whiting protein-fed groups compared to the control group, with the highest sodium intake in the BW-HA group (Table 4). Urine sodium concentration relative to creatinine was similar in the BW-WM group and control group and higher in both groups fed blue whiting protein hydrolysate, with the highest urine sodium concentration in the BW-HP group (Table 4). A strong positive correlation was observed between dietary sodium intake and urine sodium concentration (Pearson correlation 0.81 with two-tailed significance of $p=3.2 \times 10^{-6}$ ). Serum sodium concentration was within normal range for all rats (the mean for all rats was 140 with SD $1 \mathrm{mmol} / \mathrm{l}$ ) with no differences between the groups ( $p$ ANOVA $=0.98$, data not presented).

\section{Blood pressure}

Systolic and diastolic blood pressures were similar between groups at baseline ( $p$ ANOVA values were 0.31 and 0.39, respectively, Table 4). After 5 weeks intervention, the increases in both systolic and diastolic blood pressure were significantly smaller in the BW-WM group ( $p$ values 0.014 and 0.010 , respectively), BW-HA group ( $p$ values 0.032 and 0.025 , respectively) and BW-HP group ( $p$ values 0.0066 and 0.029 , respectively) when compared to the control group (Figs. 1a, b). The increase from baseline to end point in systolic and diastolic blood pressures was similar between all groups fed blue whiting protein diets. The systolic and diastolic blood pressures were strongly correlated (Pearson correlation was 0.97 with two-tailed significance of $p=1.6 \times 10^{-29}$ ).

\section{Renin and ACE inhibition by dietary proteins}

For renin activity inhibition, no measurable inhibition was detected for casein, therefore casein was not included in 
Table 3 Dietary content of indispensable amino acids, non-proteogenic amino acids, arginine, taurine, and fatty acids

\begin{tabular}{|c|c|c|c|c|}
\hline & Control diet & BW-WM diet & BW-HA diet & BW-HP diet \\
\hline \multicolumn{5}{|l|}{ Amino acids ( $\mathrm{g} / \mathrm{kg}$ diet $)$} \\
\hline Arginine & 6.9 & 9.4 & 9.6 & 9.2 \\
\hline$\beta$-alanine ${ }^{b}$ & ND & 0.20 & 0.48 & 0.40 \\
\hline Citrulline $^{\mathrm{b}}$ & ND & ND & ND & ND \\
\hline$\gamma$-aminobutyric acid ${ }^{b}$ & 0.03 & 0.01 & 0.01 & 0.01 \\
\hline Histidine & 5.6 & 5.2 & 5.2 & 4.9 \\
\hline 4-Hydroxyproline ${ }^{b}$ & ND & 0.54 & 0.57 & 0.42 \\
\hline Isoleucine & 10.2 & 9.8 & 9.7 & 8.9 \\
\hline Leucine & 18.3 & 17.0 & 18.0 & 17.0 \\
\hline Lysine & 16.4 & 18.0 & 19.0 & 18.0 \\
\hline Methionine & 6.9 & 7.5 & 7.3 & 7.4 \\
\hline 1-Methylhistidine ${ }^{\mathrm{b}}$ & ND & 0.03 & 0.02 & 0.03 \\
\hline 3-Methylhistidine ${ }^{\mathrm{b}}$ & ND & 0.37 & 0.94 & 0.72 \\
\hline Phenylalanine & 10.1 & 9.5 & 9.3 & 8.5 \\
\hline Threonine & 8.5 & 8.6 & 8.6 & 7.9 \\
\hline Valine & 13.0 & 13.0 & 13.0 & 12.0 \\
\hline Taurine $^{\mathrm{b}}$ & ND & 0.34 & 1.05 & 0.75 \\
\hline \multicolumn{5}{|l|}{ Fatty acids $^{\mathrm{b}}(\mathrm{g} / \mathrm{kg}$ diet $)$} \\
\hline $16: 0$ & 6.7 & 7.2 & 6.9 & 6.1 \\
\hline 18:0 & 2.3 & 2.4 & 2.4 & 2.1 \\
\hline $18: 1 \mathrm{n}-9$ & 12.4 & 13.0 & 13.2 & 11.7 \\
\hline $18: 1 \mathrm{n}-7$ & 0.8 & 0.9 & 0.8 & 0.7 \\
\hline $18: 2 n-6$ & 29.0 & 29.7 & 31.1 & 27.5 \\
\hline $20: 4 n-6$ & ND & 0.04 & ND & ND \\
\hline $18: 3 n-3$ & 3.4 & 3.5 & 3.7 & 3.3 \\
\hline $20: 5 n-3$ & ND & 0.30 & ND & ND \\
\hline $22: 5 n-3$ & ND & 0.03 & ND & ND \\
\hline $22: 6 n-3$ & ND & 0.77 & ND & ND \\
\hline
\end{tabular}

$B W$-WM blue whiting whole meal, $B W$-HA blue whiting protein hydrolysate prepared with Alcalase ${ }^{\circledR}, B W$ $H P$ blue whiting protein hydrolysate prepared with Protamex ${ }^{\circledR}, N D$ not detected

${ }^{a}$ Measured in diets after $\mathrm{HCl}$-hydrolysis

${ }^{\mathrm{b}}$ Only fatty acids found in concentrations $>0.5 \mathrm{~g} / \mathrm{kg}$ diet, $20: 4 \mathrm{n}-6$ and long chain $\mathrm{n}-3$ polyunsaturated fatty acids (20:5n-3, 22:5n-3, 22:6n-3) are shown the ANOVA analysis. The capacity for in vitro inhibition of renin activity was found to be most potent for BW-HP and slightly lower for BW-HA and BW-WM (Fig. 2a). The capacity for in vitro ACE inhibition was similar for casein, BW-WM protein and BW-HP protein, while the IC50 value for BW-HA protein was significantly higher (i.e., less potent) than the other dietary proteins including casein (Fig. 2b).

\section{Markers of kidney function, organ damage, inflammation and oxidative status}

Serum concentrations of creatinine, cystatin C, alanine transaminase and aspartate transaminase were not significantly different between the experimental groups (Table 5). Also, no difference was seen between the groups for urine creatinine concentration. Urine concentrations (relative to creatinine) of total protein and cystatin $\mathrm{C}$ were abnormally high and comparable to concentrations previously seen in obese Zucker fa/fa rats with prominent hyperperfusion damage in podocytes $[25,40]$, but concentrations were similar in all groups (Table 5). Urine carbamide and uric acid concentrations were also abnormally high; however, the carbamide concentration was lower in all blue whiting protein-fed groups compared to the control group and uric acid concentration was lower in the BW-HA-fed rats, but similar in BW-WM and BW-HP-fed rats when compared to controls. The ammonium urine concentration was lower in the BW-HA and WW-HP groups when compared to the control and BW-WM groups. TIM-1 was found in kidneys from all rats in amounts ranging from 3 to $134 \mathrm{pg} / \mathrm{mg}$ protein, with no differences between the groups (data not presented, $p$ ANOVA 0.57). 
Table 4 Body weight, growth, body weight-to-body length ratio, WATepi weight, blood pressure, and dietary intake and urine output of sodium (Means and standard deviations)

Control group BW-WM group BW-HA group BW-HP group ANOVA

$p$

\begin{tabular}{|c|c|c|c|c|c|}
\hline Body weight $(\mathrm{g})$ at baseline & $318 \pm 8$ & $325 \pm 11$ & $311 \pm 7$ & $323 \pm 13$ & 0.11 \\
\hline Growth ( $\%$ change in body weight from baseline to end point) & $72 \pm 8^{\mathrm{a}}$ & $76 \pm 16^{\mathrm{ab}}$ & $91 \pm 11^{\mathrm{c}}$ & $88 \pm 4^{\mathrm{bc}}$ & 0.030 \\
\hline Body weight-to-body length ratio $\left(\mathrm{kg} / \mathrm{m}^{2}\right)$ at end point & $10.0 \pm 0.6$ & $10.1 \pm 0.8$ & $10.5 \pm 0.5$ & $10.8 \pm 0.4$ & 0.092 \\
\hline WATepi (g/kg BW) & $29 \pm 2$ & $27 \pm 3$ & $31 \pm 3$ & $32 \pm 4$ & 0.12 \\
\hline Energy intake (kJ/kg BW/24 h) & $863 \pm 69$ & $865 \pm 183$ & $943 \pm 53$ & $928 \pm 66$ & 0.48 \\
\hline Protein intake (g/kg BW/24 h) & $9.4 \pm 0.75$ & $9.4 \pm 1.99$ & $10.4 \pm 0.58$ & $10.2 \pm 0.72$ & 0.40 \\
\hline Systolic blood pressure $(\mathrm{mmHg})$ at baseline & $114 \pm 11$ & $125 \pm 9$ & $123 \pm 13$ & $127 \pm 15$ & 0.31 \\
\hline Diastolic blood pressure $(\mathrm{mmHg})$ at baseline & $79 \pm 11$ & $89 \pm 10$ & $86 \pm 11$ & $88 \pm 9$ & 0.39 \\
\hline Sodium intake (mg/kg BW/24 h) & $89 \pm 7^{\mathrm{a}}$ & $122 \pm 26^{\mathrm{b}}$ & $208 \pm 12^{\mathrm{c}}$ & $183 \pm 13^{\mathrm{d}}$ & $5.8 \times 10-{ }^{10}$ \\
\hline Urine sodium (mmol/mmol creatinine) & $21 \pm 2^{\mathrm{a}}$ & $23 \pm 5^{\mathrm{a}}$ & $29 \pm 3^{b}$ & $34 \pm 2^{\mathrm{c}}$ & $1.3 \times 10-{ }^{5}$ \\
\hline
\end{tabular}

Data are presented as mean \pm standard deviation for $N=5$ rats in the control group, $N=6$ rats in the BW-WM group, $N=6$ rats in the BW-HA group and $N=6$ rats in the BW-HP group. $p$ values are shown for the comparisons of BW-WM group, BW-HA group, BW-HP group and control group using one-way ANOVA and the $p$ values in the table show results from the one-way ANOVA comparisons. Fisher's LSD was used as post hoc test when appropriate, and different letters indicate significant differences between groups

$B W$-WM blue whiting whole meal, $B W$ - $H A$ blue whiting protein hydrolysate prepared with Alcalase ${ }^{\circledR}, B W-H P$ blue whiting protein hydrolysate prepared with Protamex ${ }^{\circledR}$, WATepi epididymal white adipose tissue, ANOVA analysis of variance, LSD least significant difference

$p<0.05$ was considered significant

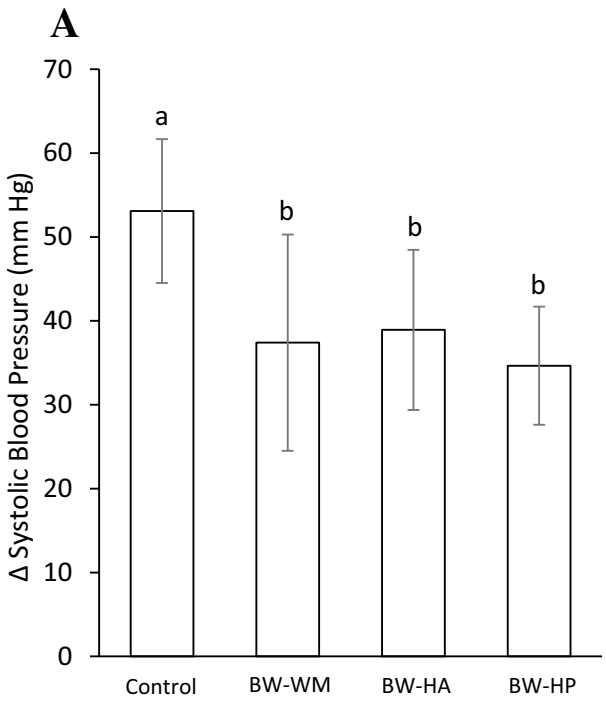

Fig. 1 Increases in mean systolic blood pressure (a) and diastolic blood pressure (b) from baseline to end point. The figure shows values as the mean with their standard deviation shown by vertical bars for $N=5$ rats in the control group, $N=6$ rats in the BW-WM group, $N=6$ rats in the BW-HA group and $N=6$ rats in the BW-HP group. BW-WM group, BW-HA group, BW-HP group and control group were compared using one-way ANOVA. $p$ ANOVA values were

Serum concentrations of MCP-1, IL-1b, IL-6 and TNF $\alpha$ were similar between the experimental groups (data not presented). Plasma concentration of reduced glutathione was similar in all groups, whereas plasma concentrations

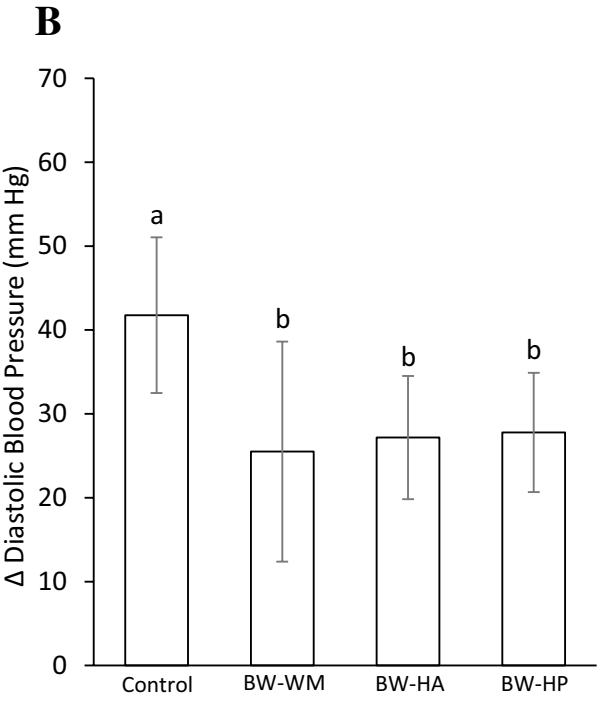

0.031 and 0.047 for comparisons of systolic and diastolic blood pressure, respectively. Fisher's LSD was used as post hoc test and different letters indicate significant differences between groups; $p<0.05$ was considered significant; $B W-W M$ blue whiting whole meal, $B W$ $H A$ blue whiting protein hydrolysate prepared with Alcalase ${ }^{\circledR}, B W$ $H P$ blue whiting protein hydrolysate prepared with Protamex $^{\circledR}$, $A N O V A$ analysis of variance, $L S D$ least significant difference

of total and oxidized glutathione were significantly higher in the BW-WM group when compared to the control group, with no differences for either of these between the other groups (Table 5). 
A

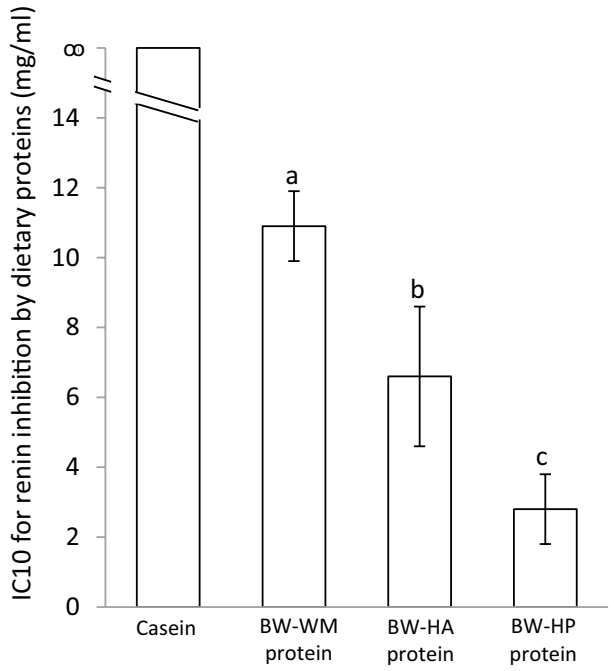

Fig. 2 IC10 values for renin inhibition (a) and IC50 values for ACE inhibition (b) by dietary proteins. Data are presented as the amount of protein in $\mathrm{ug} / \mathrm{ml}$ needed to inhibit $10 \%$ of renin activity and $50 \%$ of the ACE activity in a $0.25 \mathrm{U}$ ACE assay, respectively. Data are presented as the mean with their standard error of mean shown by vertical bars for two different measurements. The dietary proteins were compared using one-way ANOVA. Casein was not included in the ANOVA analysis for renin inhibition since no measurable renin

\section{B}

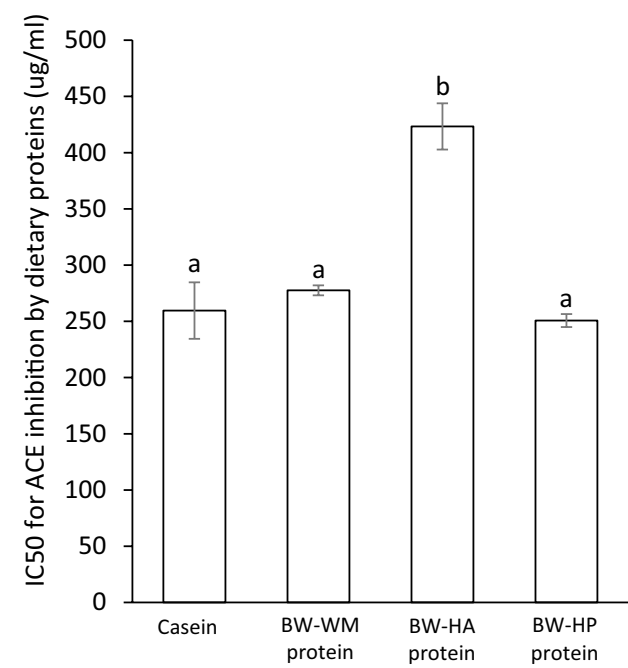

inhibition was detected for casein. Fisher's LSD was used as post hoc test and different letters indicate significant differences between proteins; $p<0.05$ was considered significant. Casein was prepared with trypsin; $B W$ - $W M$ blue whiting whole meal prepared with trypsin, $B W-H A$ blue whiting protein hydrolysate prepared with Alcalase ${ }^{\circledR}$, $B W-H P$ blue whiting protein hydrolysate prepared with Protamex ${ }^{\circledR}$, $A N O V A$ analysis of variance, $L S D$ least significant difference

Table 5 Markers of kidney function, organ damage and inflammation (Means and standard deviations)

\begin{tabular}{|c|c|c|c|c|c|}
\hline & Control group & BW-WM group & BW-HA group & BW-HP group & $\begin{array}{l}\text { ANOVA } \\
p\end{array}$ \\
\hline Serum creatinine $(\mu \mathrm{mol} / \mathrm{l})$ & $17.4 \pm 1.1$ & $17.0 \pm 1.3$ & $20.8 \pm 4.0$ & $18.0 \pm 2.1$ & 0.059 \\
\hline Serum cystatin $C(\mathrm{ng} / \mathrm{ml})$ & $2266 \pm 452$ & $2382 \pm 311$ & $2565 \pm 334$ & $2451 \pm 323$ & 0.57 \\
\hline Serum alanine transaminase $(\mathrm{U} / \mathrm{l})$ & $93 \pm 37$ & $98 \pm 52$ & $100 \pm 21$ & $86 \pm 23$ & 0.50 \\
\hline Serum aspartate transaminase (U/l) & $143 \pm 52$ & $192 \pm 134$ & $198 \pm 53$ & $143 \pm 47$ & 0.48 \\
\hline Urine creatinine $(\mathrm{mmol} / \mathrm{l})$ & $4.9 \pm 1.0$ & $3.9 \pm 1.4$ & $4.4 \pm 1.3$ & $4.8 \pm 0.8$ & 0.47 \\
\hline Urine total protein ( $\mathrm{g} / \mathrm{mmol}$ creatinine $)$ & $3.5 \pm 1.7$ & $3.8 \pm 1.0$ & $3.2 \pm 1.4$ & $3.8 \pm 0.7$ & 0.81 \\
\hline Urine cystatin $C(\mu \mathrm{g} / \mathrm{mmol}$ creatinine $)$ & $1464 \pm 891$ & $1515 \pm 175$ & $1111 \pm 323$ & $1289 \pm 298$ & 0.55 \\
\hline Urine carbamide (mmol/mmol creatinine) & $342 \pm 23^{a}$ & $278 \pm 36^{\mathrm{b}}$ & $200 \pm 15^{\mathrm{c}}$ & $254 \pm 15^{\mathrm{b}}$ & $8.3 \times 10-8$ \\
\hline Urine uric acid ( $\mu \mathrm{mol} / \mathrm{mmol}$ creatinine $)$ & $401 \pm 41^{\mathrm{a}}$ & $360 \pm 51^{\mathrm{ab}}$ & $293 \pm 39^{b}$ & $329 \pm 49^{\mathrm{ab}}$ & 0.0066 \\
\hline Urine ammonium ( $\mu \mathrm{mol} / \mathrm{mmol}$ creatinine $)$ & $40.0 \pm 16.7^{\mathrm{a}}$ & $32.3 \pm 9.0^{\mathrm{a}}$ & $20.4 \pm 2.4^{\mathrm{b}}$ & $18.5 \pm 2.3^{\mathrm{b}}$ & 0.0051 \\
\hline Plasma total glutathione $(\mu \mathrm{mol} / \mathrm{L})$ & $11 \pm 2^{\mathrm{a}}$ & $17 \pm 6^{\mathrm{b}}$ & $14 \pm 2^{\mathrm{ab}}$ & $14 \pm 2^{\mathrm{ab}}$ & 0.039 \\
\hline Plasma oxidized glutathione $(\mu \mathrm{mol} / \mathrm{L})$ & $6 \pm 1^{a}$ & $9 \pm 3^{b}$ & $7 \pm 1^{\mathrm{ab}}$ & $8 \pm 2^{\mathrm{ab}}$ & 0.049 \\
\hline Plasma reduced glutathione $(\mu \mathrm{mol} / \mathrm{L})$ & $5 \pm 1$ & $8 \pm 3$ & $7 \pm 2$ & $6 \pm 2$ & 0.33 \\
\hline
\end{tabular}

Data are presented as mean \pm standard deviation for $N=5$ rats in the control group, $N=6$ rats in the BW-WM group, $N=6$ rats in the BW-HA group and $N=6$ rats in the BW-HP group. $p$ values are shown for the comparisons of BW-WM group, BW-HA group, BW-HP group and control group using one-way ANOVA and the $p$ values in the table show results from the one-way ANOVA comparisons. Fisher's LSD was used as post hoc test when appropriate, and different letters $(a, b, c)$ indicate significant differences between groups

$B W$-WM blue whiting whole meal, $B W$-HA blue whiting protein hydrolysate prepared with Alcalase ${ }^{\circledR}, B W$ - $H P$ blue whiting protein hydrolysate prepared with Protamex ${ }^{\circledR}$, WATepi epididymal white adipose tissue, ANOVA analysis of variance, $L S D$ least significant difference

$p<0.05$ was considered significant 


\section{n-3 and n-6 PUFAs in serum, liver and WATepi}

The ratio of n-3/n-6 PUFA was higher in serum, liver and WATepi in the BW-WM group compared to the control group and both blue whiting hydrolysate groups (Supplemental Table). Rats fed BW-HA had lower ratio of n-3/n-6 ratio in serum when compared to the control group, otherwise no differences were seen in this ratio in serum, liver and WATepi for rats fed blue whiting hydrolysate diets compared to the control group. Rats fed BW-WM had higher levels of $20: 5 n-3$ and $22: 6 n-3$ in serum, higher levels of $20: 5 n-3$ and $22: 5 n-3$ in liver, and higher levels of 20:5n-3, 22:5n-3 and 22:6n-3 in WATepi. Serum level of 20:4n-6 was highest in BW-WM fed rats, but 20:4n-6 levels were not different from the other groups in liver and WATepi.

\section{Amino acids in plasma}

Plasma concentration of $\alpha$-aminobutyric acid was lower in rats fed BW-WM or BW-HA when compared to control group but was similar to the BW-HP group (Supplemental Table 2). Plasma glutamine concentration was lower in the BW-HA and BW-HP groups than in the control group, but was similar to the BW-WM group. The BW-WM fed rats had lower plasma methionine concentration compared to control rats and BW-HA-fed rats, but the concentration was similar to that in BW-HP-fed rats. Plasma taurine concentration was higher in BW-HA-fed rats compared to the control and BW-WM groups and similar to BW-HP-fed rats, with no difference between control rats and rats fed BW-WM or BW-HP diets. Plasma 3-methylhistidine concentration was higher in blue whiting protein-fed rats, in the order BW-HA > BW-HP > BW-WM > control groups. Otherwise, no differences were observed for plasma concentrations of amino acids and related compounds between the experimental groups.

\section{Amino acids in urine}

Urine concentrations (relative to creatinine) of $\gamma$-aminobutyric acid and phenylalanine were lower in all blue whiting protein-fed groups, whereas 4-hydroxyproline concentration was higher when compared to the control group (Supplemental Table 3). Asparagine concentration was lower and glycine concentration was higher in urine in the BW-WM group compared to all other groups. Urine ornithine concentration was lower in the BW-HA and BW-HP groups compared to the control and BW-WM groups, whereas threonine concentration was lower in the BW-HA and BW-HP groups compared to the control, but was similar to that of the BW-WM group. Urine $\alpha$-aminobutyric acid concentration was lower in the BW-HA group when compared to the other groups, and that of $\beta$-alanine was higher in the BW-HP group compared to BW-WM and BW-HA, but with no differences between the control group and blue whiting containing diets. The concentrations of 1-methylhistidine and 3-methylhistidine in urine were higher in rats fed BW-WM, BW-HA and BW-HP diets when compared to the control group. Urine 3-methylhistidine concentration was markedly higher in rats fed BW-HA and BW-HP diets compared to rats in the BW-WM group, whereas concentration of 1-methylhistidine was lower in rats fed BW-HA compared to the BW-WM and BW-HP groups. Urine taurine concentration was higher in the BW-HP group compared to BW-WM and BW-HA, but was similar to that of the control group. The total amount of free proteinogenic amino acids in urine was not different between the groups ( $p$ ANOVA $=0.20$, data not presented).

\section{Discussion}

In the present study, we show that diets containing $1 / 3$ of total protein as blue whiting protein from either whole meal or protein hydrolysates attenuated the development of high blood pressure in obese Zucker fa/fa rats, but did not affect markers of kidney function, organ damage or inflammation. We chose to use obese Zucker fa/fa rats aged 8-9 weeks at the start of the intervention, since these rats develop an increase in blood pressure already before the age of 10 weeks [15-17] and spontaneously develop proteinuria and renal failure as they get older [18]. The obese Zucker fa/ fa rats is considered to be a valuable experimental model for hypertension as it develops an age-related increase in blood pressure, as is also seen in humans [41].

The ability of the blue whiting proteins to attenuate the development of high blood pressure in obese Zucker fa/fa rats in the present study could be caused by the presence of bioactive peptides, e.g., peptides with physiological effects beyond being suppliers of amino acids, since antihypertensive peptides taken orally has been retrieved in its intact form in plasma in both rats and humans [42]. Blue whiting protein hydrolysates [23, 24] and Atlantic cod protein [19, $20,43,44]$ have been shown to inhibit ACE activity in vitro, and in addition Atlantic cod proteins are potent inhibitors of in vitro renin activity $[19,44]$. Renin and ACE affect blood pressure by converting angiotensinogen via angiotensin I to the active vasoconstrictor angiotensin II in the circulation, and therefore inhibition of renin and/or ACE may lower blood pressure through reduced production of angiotensin II. All three blue whiting meals inhibited renin activity in vitro, whereas casein showed no measurable effect on renin inhibition. Renin is considered to be the rate-determining enzyme for production of angiotensin II [14], thus our findings from in vitro renin inhibition is in line with the lower blood pressure development in the blue whiting protein-fed rats. 
Compared to casein, ACE IC50 values of the blue whiting proteins were similar (BW-WM and BW-HP) or higher (BWHA) and therefore did not correspond to the observed effects on blood pressure. Assessments of renin and ACE inhibitory activities of the protein hydrolysates with an in vitro assay are not sufficient for concluding whether the effects on blood pressure observed in vivo may or may not involve the ACE pathway. However, the findings that the stronger renin inhibitory in vitro activity of the blue whiting meals corresponds to the attenuated blood pressure increase in rats fed blue whiting diets are of interest and suggest that the blood pressure regulation may be mediated through the renin-angiotensin system.

Proteinuria develops in the obese Zucker fa/fa rat already at around age 10 weeks [45] and decreased renal function is seen in obese Zucker fa/fa rats at around 12 weeks age [46], thus elevated urine concentrations (relative to creatinine) of total protein, free proteinogenic amino acids, cystatin C, carbamide and uric acid could be expected. Indeed, when compared to previous findings in male obese Zucker fa/fa rats $[20,25,40]$, the urine concentrations of total protein, free proteinogenic amino acids, cystatin $\mathrm{C}$, carbamide, uric acid and ammonium were abnormally high in all experimental groups with no difference between control group and blue whiting protein-fed groups, thus indicating renal dysfunction in all groups. Amino acids filtered by the glomeruli will normally be reabsorbed by the tubules and are therefore not excreted in urine [47], and the presence of proteins and amino acids in urine is amongst the earliest sign of almost all renal diseases in both humans and animals [48-50]. Serum creatinine is a commonly used marker of kidney function, since it is produced at a relatively constant rate mainly depending on the muscle mass, muscle function, diet and health status [51]. However, serum cystatin C [52] and urine cystatin $C[53,54]$ are considered to be better markers than serum creatinine for early detection of renal damage, in addition to the presence of proteins in urine [48]. Here, we found no differences between the groups for serum concentrations of creatinine and cystatin C. TIM-1 has emerged as a useful early indicator of tubular injury as TIM-1 is not detectable in normal kidney tissue, but is expressed on the proximal tubule apical membrane in response to renal injury [55]. In the present study, proteins were found in urine and TIM-1 was found in kidney homogenate to a similar extent in all rats, indicating that renal injury was evident in all groups. Since no differences were seen between the groups for serum creatinine concentrations, total urine concentration of proteinogenic amino acids, renal concentration of TIM- 1 as well as concentrations of cystatin $\mathrm{C}$ in serum and urine, we conclude that dietary blue whiting proteins did not affect kidney function in these rats.

Plasma total and oxidized glutathione concentrations were higher in the BW-WM group compared to the control group, thus suggesting that the endogenous synthesis of the powerful antioxidant glutathione is upregulated, possibly to counteract and prevent lipid peroxidation in these hyperlipidemic rats [56]. Oxidative stress can potentially contribute to generation and maintenance of hypertension via inactivation of nitric oxide, which acts as vasodilator and regulates arterial tone $[57,58]$. Glutathione plays an important role in nitric oxide metabolism by preventing the negative effects of nitric oxide scavenging by superoxide, and may thereby have an important function in blood pressure regulation [59]. Thus, the higher plasma concentration of glutathione in BWWM-fed rats may partially explain the lower blood pressure increase in these rats when compared to the control group.

High fish intake [5-12] and fish oil supplementation [60] are associated with lower blood pressure. In the present study, the long-chain n-3 PUFAs 20:5n-3, 22:5n-3 and 22:6n-3 were found in the BW-WM diet, albeit in low amounts $(0.11 \mathrm{wt} \%)$, but were not detected in the control diet or in the blue whiting protein hydrolysate containing diets. In line with this, the n-3/n-6 PUFA ratio was higher in serum, liver and white adipose tissue from BW-WM fed rats compared to both control and the blue whiting protein hydrolysate groups. A higher n-3/n-6 PUFA ratio could have contributed to the lower blood pressure increase in the BW-WM group by reducing the erythrocyte cell membrane arachidonic acid content, thereby suppressing the concentration of the contractile factor thromboxane A2 [61]. In contrast, the n-3/n-6 ratio in serum was lower in rats fed BW-HA diet compared to the control group, and otherwise no differences were seen between rats fed blue whiting hydrolysate containing diets and control group for $n-3 / n-6$ ratio in serum, liver and WATepi. Since the blue whiting hydrolysate diets did not contain LC n-3 PUFA but still affected blood pressure development, it is not likely that the lower blood pressure increase in rats fed hydrolysed blue whiting proteins is mediated through n-3 PUFA and lower thromboxane A2 concentration. However, the higher n-3/n-6 PUFA may be a component in the delayed development of high blood pressure in rats fed the BW-WM diet.

Dietary factors other than peptides and long chain n-3 PUFAs, such as arginine, taurine and sodium, may have affected the blood pressure development in the present study. The higher arginine intake in the blue whiting protein-fed groups is of interest since arginine is a conditionally essential amino acid in rats [62] and serves as substrate for vascular production of the vasodilator nitric oxide [58]. Dietary supplementation of arginine has been shown to lower blood pressure in humans [63] and curb salt-induced blood pressure increase in salt-sensitive rats [64]. It has been suggested that dietary fish proteins attenuate development of hypertension due to higher arginine content in fish protein compared to casein [65]. Citrulline is a substrate for renal arginine synthesis [66], and increased citrulline accompanied by reduced 
arginine concentration in circulation has been shown in early stages of kidney disease [67]. The observation of no differences between the experimental groups for plasma and urine concentrations of citrulline and arginine further strengthens the assumption that blue whiting proteins did not affect kidney function in the present study. Still, the higher arginine intake may have contributed to the lower blood pressure increase in the blue whiting protein-fed groups.

Taurine supplementation has been shown to have antihypertensive properties in both humans and rats [68], and it has been shown that dietary taurine lower blood pressure in rats without affecting circulating or hepatic concentrations of taurine [69]. Taurine was found in all blue whiting protein containing diets, with the highest amounts in the hydrolysate diets; however, we observed no direct association between plasma taurine concentration and blood pressure development. The plasma elimination half-life for taurine after oral intake is estimated to be $<2 \mathrm{~h}$ in both rats and humans [70, $71]$, and since our rats were fasted for $12 \mathrm{~h}$ before blood sampling, the lack of association between dietary taurine intake and plasma concentration of taurine can most likely be explained by the rapid turnover of taurine. The higher dietary intake of taurine in rats fed blue whiting protein diets may be among the nutrients contributing to the lower blood pressure increase in these groups.

High sodium intake can increase blood pressure, as sodium acts as a vasoconstrictor and controls blood volume by increasing arterial constriction and peripheral vascular resistance [72]. Despite the higher sodium intake in blue whiting protein-fed rats when compared to the control rats, the blood pressure increase was lower in blue whiting protein-fed rats and circulating sodium concentrations were similar in all groups. The strong positive correlation between dietary sodium intake and urine sodium excretion indicates that the kidneys in rats fed blue whiting protein diets coped well with the higher sodium dietary load by excreting sodium in the urine and maintaining serum sodium concentration within normal range. However, we cannot exclude the possibility that the blue whiting proteins might have had more pronounced effect on the blood pressure development in the rats if the sodium content was lower in the diets, especially in the BW-HA and BW-HP groups.

Diets containing the blue whiting proteins seem to have little effects on the concentrations of proteinogenic amino acids in plasma and urine when compared to the control diet, whereas concentrations of non-proteinogenic amino acids differed to a larger extent between the groups. We have recently shown that serum and urine concentrations of 1-methylhistidine were increased after 8 weeks with a weekly intake of $750 \mathrm{~g}$ of Atlantic cod fillet in healthy adults with overweight/obesity, whereas serum and urine concentrations of 3-methylhistidine were not affected [73]. When obese Zucker fa/fa rats were fed diets containing Atlantic cod fillet proteins ( $25 \%$ of total protein intake), we found higher concentrations of 1-methylhistidine and 3-methylhistidine in both plasma and urine when compared to rats fed diets containing milk proteins as the sole protein source [20]. In the present study, 3 -methylhistidine and $\beta$-alanine were detected only in diets containing blue whiting protein meals after HCl-hydrolysis, with the highest levels in BW-HA and BW-HP, whereas 1-methylhystidine was found in comparable amounts in the three blue whiting diets and not in the control diet. 1- and 3-methylhistidine are also found in rat muscle in anserine (a dipeptide of $\beta$-alanine and 1-methylhistidine) and carnosine (a dipeptide of $\beta$-alanine and histidine), and in skeletal and intestinal muscle proteins [74, 75]. Although elevated plasma and urine concentration of 3-MeHis could indicate increased proteolysis, this is valid only when the diet is devoid of 3-MeHis. These methylhistidines are not reutilized for protein synthesis or metabolized but are excreted in the urine, and in line with the dietary contents the urine concentrations of 1- and 3-methylhistidine were higher in rats fed diets containing blue whiting protein meal, especially the hydrolysed forms. $\beta$-Alanine, on the other hand, can be metabolized to $\mathrm{CO}_{2}$, malonyl-CoA or acetyl-CoA, thus explaining the smaller differences in urine $\beta$-alanine concentrations between the dietary groups when compared to the concentrations of the methylhistidines. Thus, the higher urine and plasma concentrations of 3-methylhistidine in rats fed diets containing blue whiting proteins are most likely reflections of the dietary intake and not of muscle protein catabolism.

4-Hydroxyproline was found only in diets containing blue whiting proteins, and rats fed these diets had higher urine 4-hydroxyproline concentration compared to the control group. 4-Hydroxyproline is excreted mainly by the lungs (about $75 \%$ ) as $\mathrm{CO}_{2}$ and by the kidneys (25\%) primarily as proline-hydroxyproline and glycine-proline-hydroxyproline due to low peptidase activity [76]. Thus, the higher urine 4-hydroxyproline in blue whiting protein-fed rats probably does not indicate a larger degradation of collagen in connective tissue in these rats, but is most likely a reflection of the 4-hydroxyproline intake.

The present study has some methodological strengths and limitations. Dietary sodium content was higher in all blue whiting protein diets compared to control, and although rats seemed to efficiently excrete excess sodium in urine, it is possible that the effects on blood pressure in the blue whiting protein-fed groups would have been more prominent if dietary sodium intake was lower. Blood pressure was measured using the tail-cuff method (volumepressure recording) at baseline and near end point of the intervention period. The tail-cuff method is a non-invasive and inexpensive method that does not require surgery, and was chosen instead of continuous intravascular blood pressure measured by telemetry, since comparison of these 
methods shows similar results over the physiological range of blood pressure in mice [77]. In future studies, we should consider extending the experiment until the rats reach a higher blood pressure, since we have observed in our laboratory that rats from the same breeder as used in the present study reached a blood pressure that was $15-20 \mathrm{mmHg}$ higher than at end point in the present study. Also, blood pressure should be measured weekly to better monitor blood pressure development. A strength of the present study is that we used obese Zucker fa/fa rat, which is a valuable experimental model for hypertension as it develops an age-related increase in blood pressure, as is also seen in humans [41]. This study was designed to investigate the effects of intact and hydrolysed blue whiting meals in diets with $1 / 3$ of protein from blue whiting meal on the development of high blood pressure using an experimental design that is relevant to human nutrition. To reduce the number of animals, and in line with the 3Rs, we did not include lean Zucker rats since they do not experience an increase in blood pressure as they age, at least not in the age span relevant to the present study. Assessments of renin and ACE inhibitory activities of the protein hydrolysates with an in vitro assay are not sufficient for concluding whether the lower blood pressure increase observed in vivo mediated through the ACE pathway, and in vivo analyses of ACE activity and renin activity should be implemented in future studies with similar design. The high sodium content in the fish protein hydrolysates may have affected the outcome of the study, and it is possible that the effects on blood pressure could have been even more prominent if sodium in the fish meals had been removed. Future studies with fish protein hydrolysates should aspire to remove excess sodium and at the same time retain short peptides and free amino acids, e.g., by using a reverse osmosis filter. The present study is small, but will constitute a base for sample size calculations for future studies with similar designs.

To conclude, the findings in this study demonstrate that proteins from blue whiting may attenuate the development of high blood pressure in obese Zucker fa/fa rats, and the effect was similar for intact and enzymatically hydrolysed blue whiting proteins. Our in vitro studies suggest that the effects of blue whiting protein on blood pressure development may be mediated through the renin-angiotensin system, by inhibition of renin activity but not through inhibition of ACE. The blue whiting proteins did not affect markers of kidney function when compared to the control group, and all groups showed signs of poor renal function with elevated urine concentrations of proteins and cystatin $\mathrm{C}$. The findings in the present study suggest that blue whiting proteins may have a potential as functional food ingredients in the dietary prevention of high blood pressure in obesity.
Acknowledgements Open Access funding provided by University of Bergen.

Author contributions $\mathrm{AD}, \mathrm{OF}$ and $\mathrm{OAG}$ formulated the research question and designed the study. AO and OF prepared intact and hydrolysed blue whiting protein meals for the study. AD, LAV. and OAG conducted the animal study. AD, AO, SAM and OAG analysed data and performed statistical analyses. AD and OAG drafted the paper and OAG had the primary responsibility for the final content. All authors have contributed to the writing and approved the final version of the manuscript.

Funding This work was supported by the Norwegian Research Council (Project No. 245097) and TripleNine Vedde AS. The sponsors were not involved in on-site data collection, analysis and interpretation of data, writing of the article or in the decision to submit the article for publication.

\section{Compliance with ethical standards}

Conflict of interest Ola Flesland and Aslaug Drotningsvik were employed at TripleNine Vedde AS (a producer of fish meal and fish oil for the aquaculture, agriculture, pet food industry and for human consumption) during the time this study was planned and conducted. Aslaug Drotningsvik was employed as an industrial Ph.D. candidate at TripleNine Vedde AS in cooperation with the Norwegian Research Council and the University of Bergen. The other authors declare no conflicts of interest.

Open Access This article is licensed under a Creative Commons Attribution 4.0 International License, which permits use, sharing, adaptation, distribution and reproduction in any medium or format, as long as you give appropriate credit to the original author(s) and the source, provide a link to the Creative Commons licence, and indicate if changes were made. The images or other third party material in this article are included in the article's Creative Commons licence, unless indicated otherwise in a credit line to the material. If material is not included in the article's Creative Commons licence and your intended use is not permitted by statutory regulation or exceeds the permitted use, you will need to obtain permission directly from the copyright holder. To view a copy of this licence, visit http://creativecommons.org/licenses/by/4.0/.

\section{Reference}

1. Stokes J 3rd, Kannel WB, Wolf PA, D'Agostino RB, Cupples LA (1989) Blood pressure as a risk factor for cardiovascular disease. The Framingham Study-30 years of follow-up. Hypertension 13:I13-I18

2. Lewington S, Clarke R, Qizilbash N, Peto R, Collins R, Prospective studies C (2002) Age-specific relevance of usual blood pressure to vascular mortality: a meta-analysis of individual data for one million adults in 61 prospective studies. Lancet 360:1903-1913

3. Global burden of metabolic risk factors for chronic diseases $\mathrm{C}$ (2014) Cardiovascular disease, chronic kidney disease, and diabetes mortality burden of cardiometabolic risk factors from 1980 to 2010: a comparative risk assessment. Lancet Diabetes Endocrinol 2:634-647

4. Appel LJ, Brands MW, Daniels SR, Karanja N, Elmer PJ, Sacks FM, American Heart Association (2006) Dietary approaches to 
prevent and treat hypertension: a scientific statement from the American Heart Association. Hypertension 47:296-308

5. Erkkila AT, Schwab US, de Mello VD, Lappalainen T, Mussalo H, Lehto S, Kemi V, Lamberg-Allardt C, Uusitupa MI (2008) Effects of fatty and lean fish intake on blood pressure in subjects with coronary heart disease using multiple medications. Eur J Nutr 47:319-328

6. Julian-Almarcegui C, Vandevijvere S, Gottrand F, Beghin L, Dallongeville J, Sjostrom M, Leclercq C, Manios Y, Widhalm K, De Ferreira Morares AC, Gonzalez-Gross M, Stehle P, Castillo MJ, Moreno LA, Kersting M, Vyncke K, De Henauw S, Huybrechts I (2016) Association of heart rate and blood pressure among European adolescents with usual food consumption: The HELENA study. Nutr Metab Cardiovasc Dis 26:541-548

7. Del Brutto OH, Mera RM, Gillman J, Castillo PR, Zambrano M, Ha JE (2016) Dietary oily fish intake and blood pressure levels: a population-based study. J Clin Hypertens (Greenwich) 18:337-341

8. Panagiotakos DB, Zeimbekis A, Boutziouka V, Economou M, Kourlaba G, Toutouzas P, Polychronopoulos E (2007) Long-term fish intake is associated with better lipid profile, arterial blood pressure, and blood glucose levels in elderly people from Mediterranean islands (MEDIS epidemiological study). Med Sci Monit 13(7):CR307-CR312

9. Ramel A, Martinez JA, Kiely M, Bandarra NM, Thorsdottir I (2010) Moderate consumption of fatty fish reduces diastolic blood pressure in overweight and obese European young adults during energy restriction. Nutrition 26:168-174

10. Zaribaf F, Falahi E, Barak F, Heidari M, Keshteli AH, Yazdannik A, Esmaillzadeh A (2014) Fish consumption is inversely associated with the metabolic syndrome. Eur J Clin Nutr 68:474-480

11. Ke L, Ho J, Feng J, Mpofu E, Dibley MJ, Feng X, Van F, Leong S, Lau W, Lueng P, Kowk C, Li Y, Mason RS, Brock KE (2014) Modifiable risk factors including sunlight exposure and fish consumption are associated with risk of hypertension in a large representative population from Macau. J Steroid Biochem Mol Biol 144:152-155

12. Torris C, Molin M, Cvancarova MS (2016) Lean fish consumption is associated with lower risk of metabolic syndrome: a Norwegian cross sectional study. BMC Pub Health 16:347

13. Ngo DH, Vo TS, Ngo DN, Wijesekara I, Kim SK (2012) Biological activities and potential health benefits of bioactive peptides derived from marine organisms. Int J Biol Macromol 51:378-383

14. Zaman MA, Oparil S, Calhoun DA (2002) Drugs targeting the renin-angiotensin-aldosterone system. Nat Rev Drug Discov $1: 621-636$

15. de Artinano AA, Castro MM (2009) Experimental rat models to study the metabolic syndrome. Br J Nutr 102:1246-1253

16. Luo H, Wang X, Chen C, Wang J, Zou X, Li C, Xu Z, Yang X, Shi W, Zeng C (2015) Oxidative stress causes imbalance of renal renin angiotensin system (RAS) components and hypertension in obese Zucker rats. J Am Heart Assoc 4:e001559

17. Kurtz TW, Morris RC, Pershadsingh HA (1989) The Zucker fatty rat as a genetic model of obesity and hypertension. Hypertension 13:896-901

18. Coimbra TM, Janssen U, Grone HJ, Ostendorf T, Kunter U, Schmidt H, Brabant G, Floege J (2000) Early events leading to renal injury in obese Zucker (fatty) rats with type II diabetes. Kidney Int 57:167-182

19. Vildmyren I, Drotningsvik A, Oterhals A, Ween O, Halstensen A, Gudbrandsen OA (2018) Cod residual protein prevented blood pressure increase in Zucker fa/fa Rats, possibly by inhibiting activities of angiotensin-converting enzyme and renin. Nutrients 10:1820

20. Drotningsvik A, Midttun O, McCann A, Ueland PM, Hogoy I, Gudbrandsen OA (2018) Dietary intake of cod protein beneficially affects concentrations of urinary markers of kidney function and results in lower urinary loss of amino acids in obese Zucker fa/fa rats. Br J Nutr 120:740-750

21. Torry research station. Handling and processing blue whiting https://www.fao.org/wairdocs/tan/x5952e/x5952e00.htm\#Conte nts: FAO; 2001. Available from: https://www.fao.org/wairdocs/ tan/x5952e/x5952e00.htm\#Contents. Accessed 7 Aug 2018

22. Drotningsvik A, Vikoren LA, Mjos SA, Oterhals A, Pampanin D, Flesland O, Gudbrandsen OA (2018) Water-soluble fish protein intake led to lower serum and liver cholesterol concentrations in obese Zucker fa/fa Rats. Mar Drugs 16:149

23. Geirsdottir M, Sigurgisladottir S, Hamaguchi PY, Thorkelsson G, Johannsson R, Kristinsson HG, Kristjansson MM (2011) Enzymatic hydrolysis of blue whiting (Micromesistius poutassou); functional and bioactive properties. J Food Sci 76:C14-20

24. Garcia-Moreno PJ, Perez-Galvez R, Espejo-Carpio FJ, RuizQuesada C, Perez-Morilla AI, Martinez-Agustin O, Guadix A, Guadix EM (2017) Functional, bioactive and antigenicity properties of blue whiting protein hydrolysates: effect of enzymatic treatment and degree of hydrolysis. J Sci Food Agric 97:299-308

25. Vikoren LA, Drotningsvik A, Mwakimonga A, Leh S, Mellgren G, Gudbrandsen OA (2018) Diets containing salmon fillet delay development of high blood pressure and hyperfusion damage in kidneys in obese Zucker fa/fa rats. J Am Soc Hypertens 12:294-302

26. Reeves PG, Nielsen FH, Fahey GC Jr (1993) AIN-93 purified diets for laboratory rodents: final report of the American Institute of Nutrition ad hoc writing committee on the reformulation of the AIN-76A rodent diet. J Nutr 123:1939-1951

27. Reeves PG (1996) AIN-93 purified diets for the study of trace element metabolism in rodents. In: Watson RR (ed) In: Trace elements in laboratory rodents. CRC Press Inc., Boca Raton USA, pp 3-37

28. Dunn MA, Hartsook EW (1980) Comparative amino acid and protein metabolism in obese and non-obese Zucker rats. J Nutr 110:1865-1879

29. Cohen SA, Michaud DP (1993) Synthesis of a fluorescent derivatizing reagent, 6-aminoquinolyl-n-hydroxysuccinimidyl carbamate, and its application for the analysis of hydrolysate amino acids via high-performance liquid chromatography. Anal Biochem 211:279-287

30. International organization for standardization (1998) Animal feeding stuffs, animal products, and faeces or urine: determination of gross calorific value: bomb calorimeter method (ISO 9831:1998)

31. International organization for standardization (2000) Animal feeding stuffs: determination of the contents of calcium, copper, iron, magnesium, manganese, potassium, sodium and zinc: method using atomic absorption spectrometry (ISO 6869:2000)

32. International organization for standardization. Animal feeding stuffs: determination of nitrogen content and calculation of crude protein content: part 2: block digestion and steam distillation method (ISO 5983-2:2009). https://www.iso.org/standard/52199 .html. Accessed 19 Mar 2019

33. Bligh EG, Dyer WJ (1959) A rapid method of total lipid extraction and purification. Can J Biochem Physiol 37:911-917

34. International organization for standardization. Animal feeding stuffs: determination of moisture and other volatile matter content (ISO 6496:1999). https://www.iso.org/standard/12871.html. Accessed 19 Mar 2019

35. International organization for standardization. Animal feeding stuffs: determination of crude ash (ISO 5984:2002). https://www. iso.org/standard/37272.html. Accessed 1 Apr 2019

36. Oterhals A, Samuelsen TA (2015) Plasticization effect of solubles in fishmeal. Food Res Int 69:313-321 
37. Shalaby SM, Zakora M, Otte J (2006) Performance of two commonly used angiotensin-converting enzyme inhibition assays using FA-PGG and HHL as substrates. J Dairy Res 73:178-186

38. Bradford MM (1976) A rapid and sensitive method for the quantitation of microgram quantities of protein utilizing the principle of protein-dye binding. Anal Biochem 72:248-254

39. Drotningsvik A, Mjos SA, Hogoy I, Remman T, Gudbrandsen OA (2015) A low dietary intake of cod protein is sufficient to increase growth, improve serum and tissue fatty acid compositions, and lower serum postprandial glucose and fasting non-esterified fatty acid concentrations in obese Zucker fa/fa rats. Eur J Nutr 54:1151-1160

40. Drotningsvik A, Midttun O, Vikoren LA, McCann A, Ueland PM, Mellgren G, Gudbrandsen OA (2019) Urine and plasma concentrations of amino acids and plasma vitamin status differ, and are differently affected by salmon intake, in obese Zucker fa/ fa rats with impaired kidney function and in Long-Evans rats with healthy kidneys. Br J Nutr 122:262-273

41. Franklin SS, Gustin Wt, Wong ND, Larson MG, Weber MA, Kannel WB, Levy D (1997) Hemodynamic patterns of age-related changes in blood pressure. The Framingham heart study. Circulation 96:308-315

42. Shen W, Matsui T (2017) Current knowledge of intestinal absorption of bioactive peptides. Food Funct 8:4306-4314

43. Jensen IJ, Eysturskareth J, Madetoja M, Eilertsen KE (2014) The potential of cod hydrolyzate to inhibit blood pressure in spontaneously hypertensive rats. Nutr Res 34:168-173

44. Girgih AT, Nwachukwu ID, Hasan F, Fagbemi TN, Gill T, Aluko RE (2015) Kinetics of the inhibition of renin and angiotensin I-converting enzyme by cod (Gadus morhua) protein hydrolysates and their antihypertensive effects in spontaneously hypertensive rats. Food Nutr Res 59:29788

45. Stevenson FT, Wheeldon CM, Gades MD, van Goor H, Stern JS (2001) Hyperphagia as a mediator of renal disease initiation in obese Zucker rats. Obes Res 9:492-499

46. Laping NJ, Olson BA, Day JR, Brickson BM, Contino LC, Short BG, Ali SM, Brooks DP (1998) The age-related increase in renal clusterin mRNA is accelerated in obese Zucker rats. J Am Soc Nephrol 9:38-45

47. Garibotto G, Sofia A, Saffioti S, Bonanni A, Mannucci I, Verzola D (2010) Amino acid and protein metabolism in the human kidney and in patients with chronic kidney disease. Clin Nutr 29:424-433

48. Gross JL, de Azevedo MJ, Silveiro SP, Canani LH, Caramori ML, Zelmanovitz T (2005) Diabetic nephropathy: diagnosis, prevention, and treatment. Diabetes Care 28:164-176

49. Betts PR, Green A (1977) Plasma and urine amino acid concentrations in children with chronic renal insufficiency. Nephron 18:132-139

50. Macpherson NA, Moscarello MA, Goldberg DM (1991) Aminoaciduria is an earlier index of renal tubular damage than conventional renal disease markers in the gentamicin-rat model of acute renal failure. Clin Invest Med 14:101-110

51. Stevens LA, Coresh J, Greene T, Levey AS (2006) Assessing kidney function: measured and estimated glomerular filtration rate. N Engl J Med 354:2473-2483

52. Pucci L, Triscornia S, Lucchesi D, Fotino C, Pellegrini G, Pardini E, Miccoli R, Del Prato S, Penno G (2007) Cystatin C and estimates of renal function: searching for a better measure of kidney function in diabetic patients. Clin Chem 53:480-488

53. Conti M, Moutereau S, Zater M, Lallali K, Durrbach A, Manivet P, Eschwege P, Loric S (2006) Urinary cystatin C as a specific marker of tubular dysfunction. Clin Chem Lab Med 44:288-291

54. Togashi Y, Miyamoto Y (2013) Urinary cystatin C as a biomarker for diabetic nephropathy and its immunohistochemical localization in kidney in Zucker diabetic fatty (ZDF) rats. Exp Toxicol Pathol 65:615-622
55. van Timmeren MM, van den Heuvel MC, Bailly V, Bakker SJ, van Goor H, Stegeman CA (2007) Tubular kidney injury molecule-1 (KIM-1) in human renal disease. J Pathol 212:209-217

56. Araujo FB, Barbosa DS, Hsin CY, Maranhao RC, Abdalla DS (1995) Evaluation of oxidative stress in patients with hyperlipidemia. Atherosclerosis 117:61-71

57. Gokce N (2818S) L-arginine and hypertension. J Nutr 134:2807S-2811S (discussion 2818S-2819S)

58. Palmer RM, Ashton DS, Moncada S (1988) Vascular endothelial cells synthesize nitric oxide from L-arginine. Nature 333:664-666

59. Robaczewska J, Kedziora-Kornatowska K, Kozakiewicz M, ZarySikorska E, Pawluk H, Pawliszak W, Kedziora J (2016) Role of glutathione metabolism and glutathione-related antioxidant defense systems in hypertension. J Physiol Pharmacol 67:331-337

60. Campbell F, Dickinson HO, Critchley JA, Ford GA, Bradburn M (2013) A systematic review of fish-oil supplements for the prevention and treatment of hypertension. Eur J Prev Cardiol 20:107-120

61. van den Elsen LW, Spijkers LJ, van den Akker RF, van Winssen AM, Balvers M, Wijesinghe DS, Chalfant CE, Garssen J, Willemsen LE, Alewijnse AE, Peters SL (2014) Dietary fish oil improves endothelial function and lowers blood pressure via suppression of sphingolipid-mediated contractions in spontaneously hypertensive rats. J Hypertens 32:1050-1058 (discussion 1058)

62. McCoy RH (1949) Dietary requirements of the rat. In: Griffith JQ, Farris EJ (eds) The rat in laboratory investigation. J. B Lippincott Company, Philadelphia, pp 67-101

63. Dong JY, Qin LQ, Zhang Z, Zhao Y, Wang J, Arigoni F, Zhang W (2011) Effect of oral L-arginine supplementation on blood pressure: a meta-analysis of randomized, double-blind, placebocontrolled trials. Am Heart J 162:959-965

64. Chen PY, Sanders PW (1991) L-arginine abrogates salt-sensitive hypertension in Dahl/Rapp rats. J Clin Invest 88:1559-1567

65. Ait-Yahia D, Madani S, Savelli JL, Prost J, Bouchenak M, Belleville J (2003) Dietary fish protein lowers blood pressure and alters tissue polyunsaturated fatty acid composition in spontaneously hypertensive rats. Nutrition 19:342-346

66. Dhanakoti SN, Brosnan ME, Herzberg GR, Brosnan JT (1992) Cellular and subcellular localization of enzymes of arginine metabolism in rat kidney. Biochem J 282(Pt 2):369-375

67. Ceballos I, Chauveau P, Guerin V, Bardet J, Parvy P, Kamoun P, Jungers $P$ (1990) Early alterations of plasma free amino acids in chronic renal failure. Clin Chim Acta 188:101-108

68. Imae M, Asano T, Murakami S (2014) Potential role of taurine in the prevention of diabetes and metabolic syndrome. Amino Acids 46:81-88

69. Nara Y, Yamori Y, Lovenberg W (1978) Effect of dietary taurine on blood pressure in spontaneously hypertensive rats. Biochem Pharmacol 27:2689-2692

70. Nielsen CU, Bjerg M, Ulaganathan N, Holm R (2017) Oral and intravenous pharmacokinetics of taurine in sprague-dawley rats: the influence of dose and the possible involvement of the protoncoupled amino acid transporter, PAT1, in oral taurine absorption. Physiol Rep 5(19):e13467

71. Ghandforoush-Sattari M, Mashayekhi S, Krishna CV, Thompson JP, Routledge PA (2010) Pharmacokinetics of oral taurine in healthy volunteers. J Amino Acids 2010:346237

72. Blaustein MP, Leenen FH, Chen L, Golovina VA, Hamlyn JM, Pallone TL, Van Huysse JW, Zhang J, Wier WG (2012) How $\mathrm{NaCl}$ raises blood pressure: a new paradigm for the pathogenesis of salt-dependent hypertension. Am J Physiol Heart Circ Physiol 302:H1031-H1049

73. Hagen IV, Helland A, Bratlie M, Midttun O, McCann A, Sveier H, Rosenlund G, Mellgren G, Ueland PM, Gudbrandsen OA (2019) TMAO, creatine and 1-methylhistidine in serum and urine are potential biomarkers of cod and salmon intake: a randomised 
clinical trial in adults with overweight or obesity. Eur J Nutr. https ://doi.org/10.1007/s00394-019-02076-4

74. Davey CL (1960) The significance of carnosine and anserine in striated skeletal muscle. Arch Biochem Biophys 89:303-308

75. Millward DJ, Bates PC (1983) 3-Methylhistidine turnover in the whole body, and the contribution of skeletal muscle and intestine to urinary 3-methylhistidine excretion in the adult rat. Biochem $\mathrm{J}$ 214:607-615
76. Weiss PH, Klein L (1969) The quantitative relationship of urinary peptide hydroxyproline excretion to collagen degradation. J Clin Invest 48:1-10

77. Feng M, Whitesall S, Zhang Y, Beibel M, D’Alecy L, DiPetrillo K (2008) Validation of volume-pressure recording tail-cuff blood pressure measurements. Am J Hypertens 21:1288-1291 